\title{
高分子压電林料のアクチユエータ
}

\section{瀬尾 瘫**}

Key words: piezoelectric polymer, piezoactuator, bimorph device, multilayer bimorph, display device, light shutter

\section{1. はじめに}

近年，压電セラミックスを用いたアクチュエータの 開発が積極的に進められている。これは, 圧電アクチュ エータが従来のコイルと磁石で作られた電磁アクチュ エータに比較し, (1) 消費電力が小さい, (2)ノイズが発 生しにくい, (3) 高い位置決め分解能をもつ, (4) センサ 機能を持つなど多くの特徵をもっているためである。

また，最近圧電セラミックス同様大きな圧電効果を 有し， から，高分子特有の性質を有する高分子圧電材 料が開発され，圧電セラミックスとは異なった特徵を るつ圧電アクチュエータの開発が進められている.

ここでは, 高分子圧電材料を用いた圧電アクチュ エータの特性および応用の可能性について展望する。

\section{2. 高分子圧電材料}

高分子圧電材料には，高分子自体が圧電機能を有す
やゴムにPZT などの強誘電体微粒子を分散し, 分極 処理することにより得られる。この複合系は延伸操作 なしに大きな圧電性を得ることが可能なため押出成 形，圧縮成形などいろいろな成形方法が使用でき， 従って任意の形状に容易に成形することができる。

表 1 に高分子压電材料の諸特性を示す．高分子圧電 材料の圧電定数は無機物に比較しアクチュエータとし て重要な $d$ 定数（応力と分極々の関係）では約 $1 / 4$ で あるが, センサとして重要な $g$ 定数（加兄る応力と発 生する電圧との関係) では約 1 けた大きい。従って, 高分子圧電材料はセンサとして優れた材料であること を示唆している。また，高分子压電材料は高分子とし ての特徵, (1) 可撓性に富み, 成形加工が容易, (2) 比重 が小さく軽量, (3) 薄膜, 大面積化が容易, (4) 耐衝撃, 耐屈曲性に優れるなど無機物では望み得ないような特 徵を持っている。
るものと，高分子と PZT (チタン

酸ジルコン酸鉛) 系セラミックス を複合化することにより圧電機能 を付与したものがある，前者に代 表されるものが延伸した PVDF を分極処理したものである.この 圧電性 PVDF は延伸プロセスを 必要とするため延伸方向に対して 異方性をもっている，また，比較 的薄いフィルム状に成形すること ができる、後者の複合系は，樹脂

* 原稿受付 昭和 62 年 3 月 26 日

** 三菱油化(株)（茨城県稲敷郡阿見 町中央 8-3-1)
表 1 各種王電材料の諸特性（伸び方向の王電性）

\begin{tabular}{|c|c|c|c|c|c|c|}
\hline 材 料 特 性 & $\begin{array}{c}\text { 密 } \underset{\rho}{\text { 度 }} \\
\left(10^{-3} \mathrm{~kg} / \mathrm{cm}^{3}\right)\end{array}$ & $\begin{array}{c}\text { 弾 性率 } \\
C \\
\left(10^{3} \mathrm{~N} / \mathrm{m}^{3}\right)\end{array}$ & $\begin{array}{c}\text { 比誘電率 } \\
\varepsilon_{r}\end{array}$ & $\begin{array}{r}\text { 圧 } \\
\left.d_{3} / \mathrm{N}\right) \\
(\mathrm{pC} / \mathrm{N})\end{array}$ & $\begin{array}{l}\text { 電 定 数 } \\
\left(10^{-3} \mathrm{~g} \cdot g_{31} \cdot \mathrm{m} / \mathrm{N}\right) \\
\end{array}$ & $\begin{array}{l}\text { 最高 } \\
\text { 使用 } \\
\text { 温度 } \\
{ }^{\circ} \mathrm{C} \\
\end{array}$ \\
\hline PVDF & 1.78 & 3.0 & 13 & 20 & 174 & 80 \\
\hline (VDF 55) & 1.90 & 1.2 & 18 & 25 & 160 & 70 \\
\hline (VDF 75) & 1.88 & 2.0 & 10 & 10 & 110 & 100 \\
\hline $\mathrm{P}(\mathrm{VDCN} / \mathrm{VAc})$ & 1.20 & 4.5 & 4.5 & 6 & 169 & 160 \\
\hline $\mathrm{PVDF} / \mathrm{PZT}$ & $5.3 \sim 5.8$ & $3 \sim 6$ & $120 \sim 180$ & $20 \sim 30$ & 19 & 100 \\
\hline ゴム/PZT & 5.6 & 0.04 & 55 & 35 & 72 & 100 \\
\hline $\mathrm{POM} / \mathrm{PZT}$ & 4.5 & 2.0 & 95 & 17 & 20 & 140 \\
\hline $\mathrm{PZT}$ & 7.5 & 83.3 & 1200 & 110 & 10 & 250 \\
\hline 水晶 & 2.65 & 77.2 & 4.5 & 2 & 50 & 573 \\
\hline
\end{tabular}

PVDF：ポリふっ化ビニリデン $\mathrm{P}(\mathrm{VDF} / \mathrm{TrFE}) ：$ ふっ化ビニリデン・トリフルオロエ チレン共重合体, $\mathrm{P}(\mathrm{VDCN} / \mathrm{VAc})$ ：シアン化ビニリデン・酢酸ビニル共重合体, $\mathrm{POM}$ : ポリアセタール, PZT：チタン酸ジルコン酸鉛 


\section{3. 高分子アクチュエータ素子}

代表的な圧電アクチェエータ素子としてバイモルフ 横効果と積層縦効果素子の 2 種類がある.

バイモルフ横効果素子：厚み方向に分極された 2 枚の圧電膜が貼り合わされ，一端を固定して厚み方向 に電圧を印加すると自由端はたわみ変形する。先端変 位 $X$, 先端発生力 $F$, 共振周波数 $f_{0}$ を次式で示す.

$$
\begin{aligned}
& X=\frac{3}{4} \frac{V d_{31} L^{2}}{t^{2}} \\
& F=\frac{3}{2} \frac{C_{11} W d_{31} t V}{L} \\
& f_{0}=\frac{t}{2 \pi}\left(\frac{1.875}{L}\right)^{2} \sqrt{\frac{C_{11}}{3 \rho}}
\end{aligned}
$$

ここで, $t:$ 各層の厚さ, $L:$ 長さ, $W:$ 幅, $\rho:$ 密度, $d_{31}$ : 圧電定数, $V$ : 印加電圧, $C_{11}$ : ヤング率.

多層バイモルフの場合は次式で示される.

$$
X=\frac{3}{4} \frac{V d_{31} L^{2}}{N t^{2}}
$$

ここで, $2 N$ : 各層の総数。

$$
F=\frac{3}{2} \frac{C_{11} W d_{31} t V N^{2}}{L}
$$

積層縦効果素子： 内部に多数の電極層が埋め込ま れており，電気的に並列接続されている。電界を印加 すると $L$ 万向に変位する.

$$
\begin{aligned}
& X=\frac{L d_{33} V}{t} \\
& F=2 W d_{33} C_{33} V \\
& f_{0}=\frac{1}{2 L} \sqrt{\frac{C_{33}}{\rho}}
\end{aligned}
$$

積層型は発生力が非常に大きく，エネルギー変換効率 が高い.さらに，共振周波数が高いので高速駆動が可 能な半面, 変位量が小さいという欠点がある.

高分子複合物圧電材料を用いたバイモルフ素子につ いて直流電圧を印加した時の先端変位量を図 1 に示 す．測定には長さ $40 \mathrm{~mm}$, 幅 $10 \mathrm{~mm}$, 厚さ $100 \mu \mathrm{m}$, 圧電定数 $\left(d_{31}\right) 18.3 \mathrm{pC} / \mathrm{N}$ の短冊状のシートを分極方 向が同じ方向になるよらにエポキシ樹脂で接着し素子 として用いた。図中の実線は理論值を示しており実测 值と良く一致している。バイモルフ素子に一定時間直

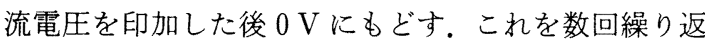
した時の先端変位をシフト变位と言う。高分子複合物 圧電材料を用いたバイモルフ素子のシフト電位は，電 圧印加を同一方向に繰り返すにつれて変位方向が同方 向であるため，次第に大きくシフトして行く、また， バイモルフ素子は最初に電圧を印加した時の変位量

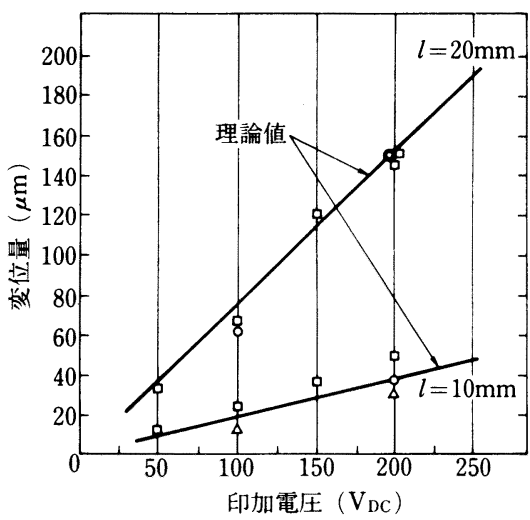

図 1 先端変位量と印加電生

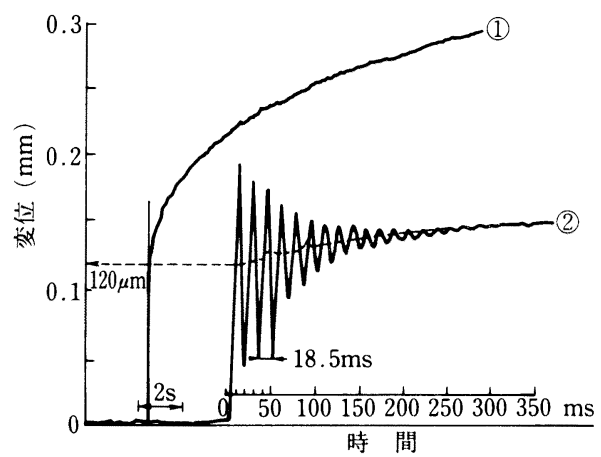

図 2 直流電圧印加後の先端の振動之変位（2)は（1)の 立上がり部分を払大したもの）

と, 再度電圧を印加した時の変位量が異なる残留変位 を示す。シフト変位，残留変位は圧電セラミックスに 比べ大きい，従って，微小変位制御する用途では問題 になると思われる，図 2 に直流電圧を急に印加したと きの先端変位の様子を示す。先端は振動した後徐々に 一定の変位になる。

先端変位の振動はバイモルフ素子固有の振動数に対 応している，以上，高分子複合物王電材料を用いた六 イモルフ特性を示した。压電セラミ゙ックスの場合と同 様，ヒステリシス，シフト特性，応答時間には現状で は問題があるが，バイモルフ素子の特性である大きな 変位は压電セラミックス以上に容易に得ることができ る。また，高分子複合物圧電材料は，(1) 成形性，加工 性に優れるため任意の形状に容易に加工できる，(2) 衝 撃, 屈曲によって破損しにくい, (3) 他材料との接着が 容易である，(4)用途に合わせた材料設計が可能であ る, (5) 機能の分担により構成材料の特徵を巧みに生か すことができるなどの特徵を有している。

王電性 PVDF は薄い膜状であるため，2枚および多 層に貼り合わせたバイモルフ素子は印加電圧の増大と ともに非常に大きく曲がり，その動きは十分目に見兄 


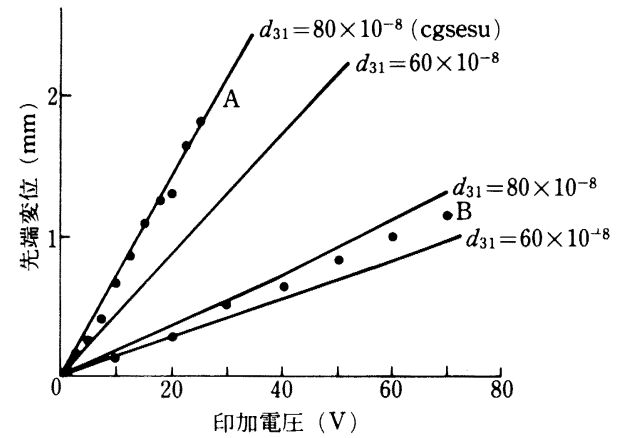

A : $N=1, \quad L=17 \mathrm{~mm}, \quad W=9.2 \mathrm{~mm} . \quad t=9 \mu \mathrm{m}$ B : $N=5, L=19.5 \mathrm{~mm}, W=9.2 \mathrm{~mm}, \quad t=9 \mu \mathrm{m}$

図 3 印加電圧と先端变位

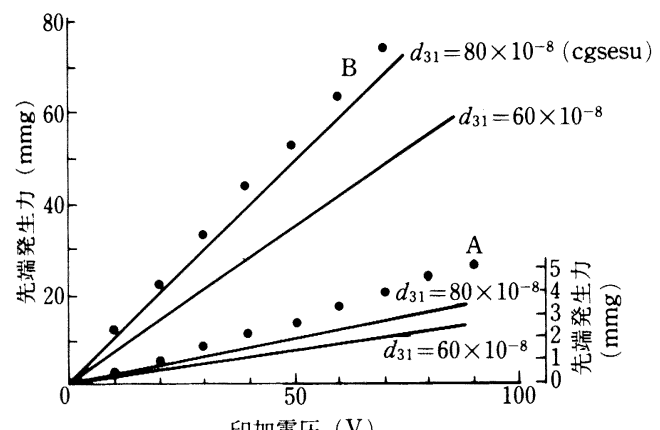

印加電压 $(\mathrm{V})$

A : $N=1, L=17 \mathrm{~mm}, \quad W=9.2 \mathrm{~mm}, \quad t=9 \mu \mathrm{m}$

B : $N=5, L=19.5 \mathrm{~mm}, W=9.2 \mathrm{~mm}, t=9 \mu \mathrm{m}$

図 4 印加電圧と先端発生力

る程に大きい，図 3, 図 4 に式 (4), (5) の計算結果(実 線) と実験結果とを比較して示す ${ }^{11}$. PVDFに関しても 高分子複合物圧電材料之同様酒流電圧を急比印加す ると先端は共振による振動をした後に一定の位置に変 位する。また，残留変位特性およびシフト特性に関し ては圧電セラミックスや高分子複合物圧電材料上り小 さい，圧電性 PVDF は高分子複合物圧電材料に比へ より薄い膜が得られることから，発生力は小さいが曲 がり変位の大きなバイモルフ素子を容易に得ることが できる，従って，PVDFが樹脂として持つ特有の性質 を利用することによって高分子複合物压電材料と同様, 新しいタイプの圧電アクチュエータが可能である。

\section{4. 高分子アクチュエータ素子の応用}

高分子压電材料を用いたアクチュエータ素子は現在 開発段階にあり，実用化されているものはない。

光ファイバ通信の応用例として高分子圧電バイモル フ素子と光ファイバを組み合わせた光スイッチがあ る2). 光ファイバ通信では, PVDF バイモルフ素子を用 いてファイバを動かし通信路を切り換える。切替えに
要する電圧, 電力共に少なく, 実際に $10 \mathrm{~V}$ 程度で 840 $\mu \mathrm{s}$ 以下の接続時間で切替觉を行うことができる。ま た, 圧電性 PVDF を薄いガラスの鏡に貼り付けて曲率 を制御できるようにし，レーザ光の波面の修正や光学 計測 ${ }^{3)}$ ，京た多数並べて立体画像再生装置 ${ }^{4)}$ の提案がな されている。このほか, バィモルフ型ディスプレ $1^{5)}$, ノートブック型ディスプレイ ${ }^{5)}$, 空のブラインド6) 等が試作されている。

$\mathrm{RCA}$ の戸田ら せたものは振動で発生する風量は少ないが, 多層にし たものはその共振点でかなりの風を発生し, ファンと して応用できることを示している。

最近, 医療や細胞生物学の分野では, 微小な作業用 アクチュエータ，すなわちマイクロマニピュレータの 需要が増している. PVDF バイモルフ素子を用いて試 作したマイクロ触刺子が微生物を取り扱らバイオマイ クロマニピュレータとして利用されている8).

以上に示したように, (1) 種々の構造のディスプレイ 素子(動きを目で見やすく表示)，光のシャッタまたは 絞り（光の通過路の断面積を変化）など光との相互作 用を応用したもの，(2)大きな接点变位を得るために高 電圧，小電流による切替学が適した接点を動かすリ レー, (3) 電磁波・高周波信号の制御, (4) 通常の小さな 電磁石により軽物体の機械的変位を必要とするところ への応用など高分子圧電アクチュエータ素子としてい ろいろの応用が試みられている。しかし，高分子圧電 アクチュエータ素子は大きな変位が得られる割に発生 力が小さいことから実用化が今一歩進まないのが現状 である，発生力を大きくするには，材料の性能（压電 定数 $d_{31}$, ヤング率 $C_{11}$ ) を向上させるとともにアク チュエータの構造（多層化など）を工夫することであ る.

\section{文献}

1) M. Toda and S. Osaka : Electromotional Device using $\mathrm{PVF}_{2}$ Multilayer Bimorph, Trans. IECE of Japan, E 61, 7 , (1978) 507.

2）小林駿介：昭和 53 年電気通信学会全国大会講演論文集 [4] (1978) 115 .

3) T. Sato, H. Ishida and O. Ikeda: Adaptive PVDF Piezoelectric Deformable Mirror System, Appl. Opt., 19, 9, (1980) 1430.

4) 佐藤拓宗：第 26 回応用物理関係連合講演会 (1979.3) 39 .

5) M. Toda and S. Osaka : Application of $\mathrm{PVF}_{2}$ Bimorph Cantilever Elements to Display Devices, Proc. S. I. D., 19, 2, (1978) 35.

6) M. Toda and S. Osaka : Large Area Electrical Controllable Light Shutter Array using $\mathrm{PVF}_{2}$ Bimorph Vanes, Ferroelectrics, 23, (1980) 121.

7) M. Toda: Theory of Air Flow Generation by a Resonant Type $\mathrm{PVF}_{2}$ Bimorph Cantilever Vibrator, Ferroelectrics, 22, (1979) 911

8) Y. Umetani : 10th ISIR, (1980) 571. 